\title{
Theoretical and Experimental Study of a Double Air-Pass Solar Thermal Collector with an Insulating Rod of Millet
}

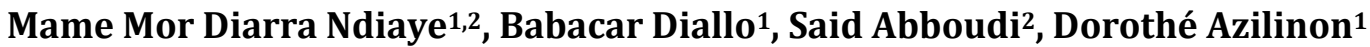 \\ ${ }^{1}$ Laboratoire d’Energétique appliquée (LEA), Ecole Supérieure Polytechnique, Dakar, Sénégal \\ ${ }^{2}$ Laboratoire Interdisciplinaire Carnot de Bourgogne (ICB), Unité Mixte de Recherche 6303, CNRS, Université de Bour gogne \\ Franche-Comté, UTBM Département COMM, Belfort, France \\ Email: mamemorndiaye@gmail.com, said.abboudi@utbm.fr, dorothe.azilinon@ucad.edu.sn, babacardiallo88@yahoo.fr
}

How to cite this paper: Ndiaye, M.M.D., Diallo, B., Abboudi, S. and Azilinon, D. (2018) Theoretical and Experimental Study of a Double Air-Pass Solar Thermal Collector with an Insulating Rod of Millet. Energy and Power Engineering, 10, 106-119. https://doi.org/10.4236/epe.2018.103008

Received: January 24, 2018

Accepted: March 27, 2018

Published: March 30, 2018

Copyright $\odot 2018$ by authors and Scientific Research Publishing Inc. This work is licensed under the Creative Commons Attribution International License (CC BY 4.0).

http://creativecommons.org/licenses/by/4.0/

\begin{abstract}
In this article, we present the study of a double-pass air insulated by crushed millet stem mixed with gum arabic. The study is carried out based on mathematical models obtained by writing energy conservation laws in the various components of the system, which made it possible to determine the evolution of the air temperature as a function of the length of the absorber and to make a comparison with the experimental results. After comparing the results obtained with those found in the literature, the influence of some physical and geometrical parameters on the performance of the solar thermal collector is presented.
\end{abstract}

\section{Keywords}

Solar Collector, Double Air-Pass, Millet Rod, Modeling, Performance

\section{Introduction}

Plan solar air collectors convert solar energy into thermal energy extracted from the air into flow in the solar collector [1]. This energy is used in a variety of applications, such as drying foodstuffs (fruit, wood, etc.) [2]-[18], heating, and so on. They have a number of practical advantages, such as the direct use of air for drying products in industry, which translates into remarkable energy savings, and this is why recent developments in the field of high environmental quality have played an important role in the design offices and particularly in the industrial sector.

To produce solar thermal energy, several types of flat solar collectors are designed for different performances [3]-[21]. Various studies on their performance have been analyzed and have shown results on the parameters of the solar col- 
lector according to their components, namely: glass, heat transfer fluid, absorber and insulation system.

The solar radiation captured has an impact on the efficiency of the solar collector [4], the increase in the contact surface of the absorber is proportional to the rate of solar radiation received by the absorber, but also increases the heat transfer coefficient between the cover and the environment.

The solar collector glazing shall have characteristics enabling it to optimize the energy transmitted to the absorber by the greenhouse effect [5]. The triple cover reduces heat loss forward more than the double cover [6]. According to Wijeysundra et al., the efficiency of the double-glazed solar collector is increased by $10 \%-15 \%$ compared to single-glazed glass [7]-[15].

The orientation of a collector has an influence on the solar radiation received by its surface [8]-[23]. The best position of the solar collector is to point it directly south.

The location of obstacles in the various channels of the solar collector influences its efficiency [9]-[17], which can reach $75 \%$ with a mass flow rate of 0.072 $\mathrm{kg} / \mathrm{s}$ and a solar radiation of $788 \mathrm{~W} / \mathrm{m}^{2}$ [10]-[22]. The finned absorber is more efficient than the finless absorber. The thermal efficiency of a double-pass solar collector with a porous medium is $60 \%$ to $70 \%, 20 \%$ to $30 \%$ higher than the collector without a porous medium [11]-[20]. Its efficiency is high compared to conventional solar collectors, it can exceed $75 \%$.

The porosity of the fluid influences the temperature increase according to the mass flow rate [12]. Elradi A. Musa and Al's work has shown that Reynolds and Nusselt numbers also have a significant effect on low porosities [13]-[19].

To do this, a mathematical model based on the solar collector thermal balance method is studied. The results of the numerical simulations were used to evaluate the temperature profiles of each solar collector layer (glass, absorber, fluid and insulating plate). In order to validate the theoretical results, numerical results obtained with Comsol code are used to compare the evolution of the thermo-physical parameters of the fluid in the solar collector. The comparative analysis of the theoretical and experimental results of the double-pass solar thermal collector has enabled the model to be validated.

\section{Experimental Device for Solar Collector}

The solar thermal collector studied is shown schematically in Figure 1. It consists of a single glass pane with a surface area of $4 \mathrm{~m}^{2}$ and a thickness of $0.005 \mathrm{~m}$ [14] [15] [16]. The greenhouse effect produced at its level causes the absorber to heat up, which is made of black painted steel sheet, $0.003 \mathrm{~m}$ thick. The insulation layer, made of crushed millet shank, $0.030 \mathrm{~m}$ thick behind the sensor and on the side, minimizes losses and therefore increases the thermal performance of the solar collector. A channel $\left(e_{\mathrm{f} 1}=0.045 \mathrm{~m}\right.$ on the outward flow and $e_{\mathrm{f} 2}=0.070 \mathrm{~m}$ on the return flow) connecting the inlet to the outl et al. lows air to be guided by forced convection through a fan placed at the outlet from which a drawn flow is drawn as shown in Figure 2. A total of 36 Thermocouples are placed along the 
length of the sensor to measure the temperature evolution of the different solar collector components, as illustrated in Figure 3.

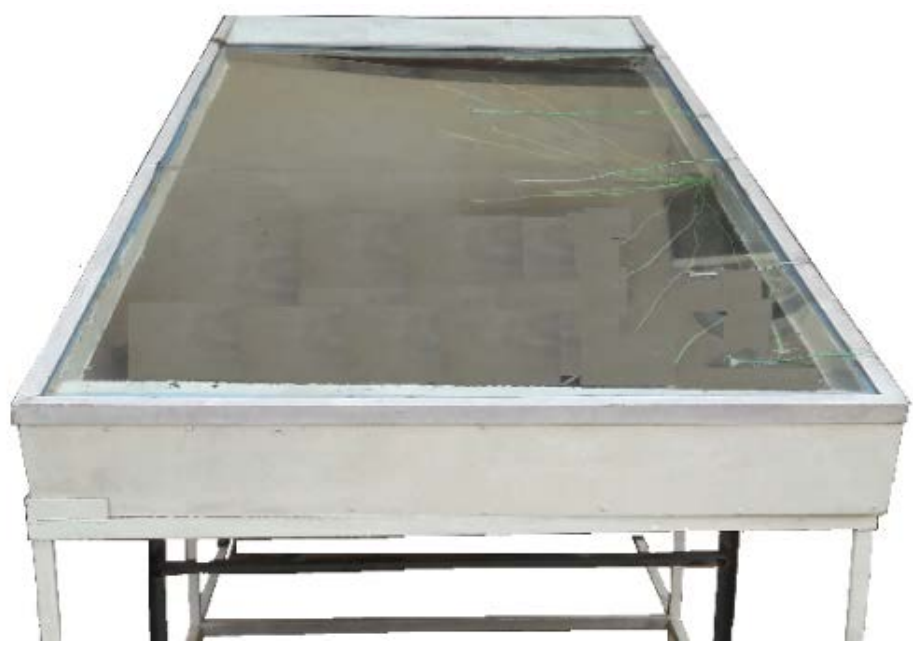

Figure 1. Picture of the double air pass solar thermal collector.

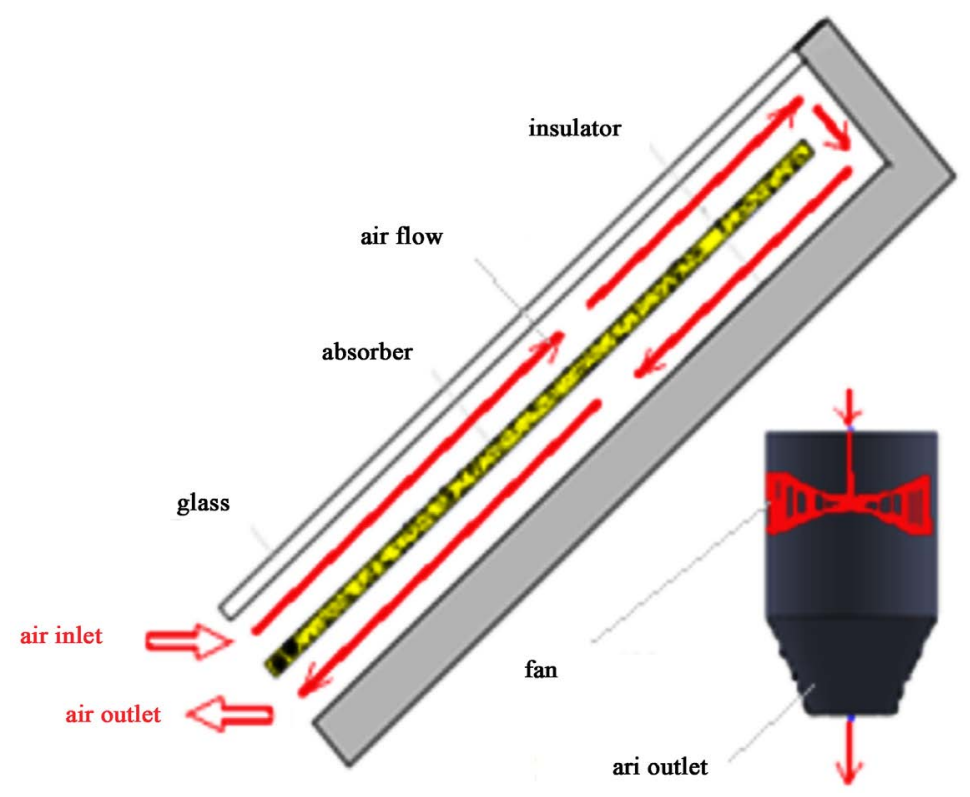

Figure 2. Diagram of the studied solar collector.

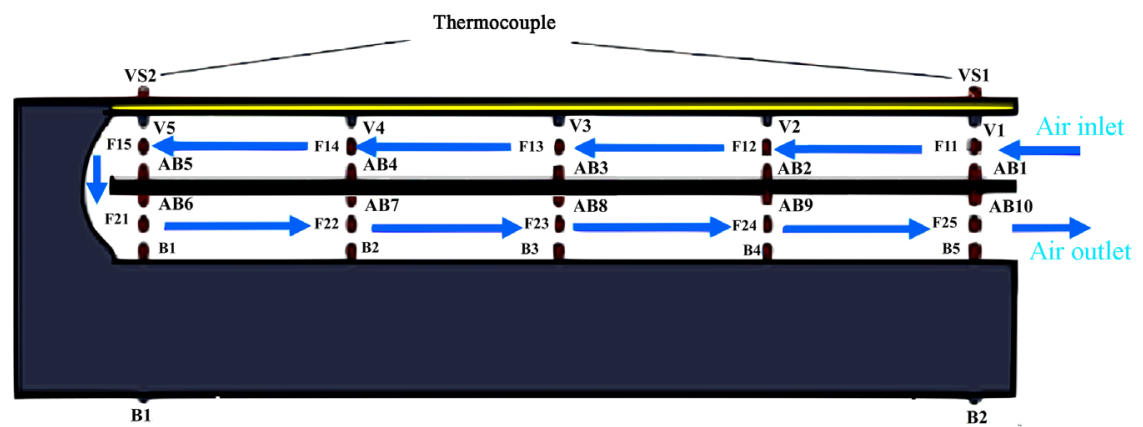

Figure 3. Position of thermocouples in the sensor collector. 
Measurement campaigns were carried out at the Polytechnic High School of Dakar in natural sunshine during the months of April and May, obtained by a pyranometer on the solar collector facing south and inclined at $15^{\circ}$.

The air at the solar collector inlet is at room temperature with fixed air flow rates measured with the anemometer. Daytime system performance is subject to outdoor conditions (solar radiation temperature). The measurements are made with a data acquisition (Agilent 34970A) equipped with two multiplexers, comprising 19 thermocouples for the first 34901A and 17 connections for the second 34908A. The Agilent data acquisition is placed underneath the solar collector with the computer. A potentiometer is used to adjust the fan speed which is proportional to the flow rate.

\section{Heat Balance Equations}

The model is based on the following assumptions:

$>$ The external and internal convective heat transfer coefficients are constant over the length of the solar collector.

$>$ The thermal conduction is neglected

$>$ The pressure losses are neglected in the side walls and at the bottom of the solar collector.

All surfaces of the different components are equal

Under the above-mentioned hypothesis, the heat balance equation of each component of the solar collector are.

Glass

$$
\begin{aligned}
& \left(\rho C_{p} e\right)_{v} \frac{\partial T_{v}}{\partial t}+h_{w} \cdot\left(T_{v}-T_{a}\right)-h_{c, v-f} \cdot\left(T_{f_{1}}-T_{v}\right)+\sigma \cdot \varepsilon_{v} \cdot\left(T_{v}^{4}-T_{c}^{4}\right) \\
& -\alpha_{v} \cdot G-\frac{\sigma}{\frac{1-\varepsilon_{a b}}{\varepsilon_{a b}}+\frac{1}{F_{v-a b}}+\frac{1-\varepsilon_{v}}{\varepsilon_{v}}}\left(T_{a b}^{4}-T_{v}^{4}\right)=0
\end{aligned}
$$

Fluid (f1)

$$
\left(\rho C_{p} e\right)_{f_{1}}\left(\frac{\partial T_{f_{1}}}{\partial t}+V_{f} \cdot \frac{\partial T_{f_{1}}}{\partial x}\right)+h_{c, v-f} \cdot\left(T_{v}-T_{f_{1}}\right)-h_{c, a b-f} \cdot\left(T_{f_{1}}-T_{a b}\right)=0
$$

\section{Absorber}

$$
\begin{aligned}
& \left(\rho \cdot C_{p} \cdot e\right)_{a b} \frac{\partial T_{a b}}{\partial t}+h_{c, v f 1-a b} \cdot\left(T_{a b}-T_{f_{1}}\right)+\sigma \cdot \mathcal{F}_{a b-v}\left(T_{a b}^{4}-T_{v}^{4}\right) \\
& -\alpha_{a b} \cdot \tau_{v} \cdot G(t)-h_{c, f-a b} \cdot\left(T_{f_{2}}-T_{a b}\right)-\sigma \cdot \mathcal{F}_{a b-p}\left(T_{p}^{4}-T_{a b}^{4}\right)=0
\end{aligned}
$$

Fluid (f2)

As the heat transfer fluid underneath the absorber exchanges with the plate (p) and the absorber ( $\mathrm{ab}$ ) by convection, then we have

$$
\left(\rho C_{p} e\right)_{f_{2}}\left\{\frac{\partial T_{f_{2}}}{\partial t}+V_{f}^{\prime} \cdot \frac{\partial T_{f_{2}}}{\partial x}\right\}+h_{c, a b-f} \cdot\left(T_{f_{2}}-T_{a b}\right)-h_{c, p-f} \cdot\left(T_{p}-T_{f_{2}}\right)=0
$$

\section{Insulation plate}




$$
\left(\rho C_{p} e\right)_{p} \frac{\partial T_{p}}{\partial t}+h_{c, p-f} \cdot\left(T_{p}-T_{f_{2}}\right)+\sigma \cdot \mathcal{F}_{p-a b}\left[T_{p}^{4}-T_{a b}^{4}\right]-h_{a r r i} \cdot\left(T_{a}-T_{p}\right)=0
$$

The modeling of the solar collector is based on a nodal discretization showing 5 knots.

\section{Heat Transfer Coefficients}

The system of equations presented in section 4 is based on a good knowledge of the heat transfer coefficients to take into account the heat exchanges, by conduction, convection and radiation, between the different components of the solar collector.

Heat transfer between celestial vault and glass

$$
\begin{gathered}
h_{h r, v-c}=\sigma \varepsilon_{v}\left(T_{c}+T_{v}\right)\left(T_{c}^{2}+T_{v}^{2}\right) \\
T_{c}=\left(T_{a}-6\right)
\end{gathered}
$$

Others use:

$$
T_{c}=0.0552\left(T_{a}\right)^{1.5}
$$

In our calculations, we will adapt this last expression for the calculation of $T_{c}$

The heat transfer between the ambient environment and the glass is given by Mac Adams' formula:

$$
h_{w}=5.7+3.8 \cdot V_{w}
$$

Radiation heat transfer:

$$
h_{r, v-a b}=\frac{\sigma}{\frac{1-\varepsilon_{a b}}{\varepsilon_{a b}}+\frac{1}{F_{a b-v}}+\frac{1-\varepsilon_{v}}{\varepsilon_{v}}}\left(T_{a b}+T_{v}\right)\left(T_{a b}^{2}+T_{v}^{2}\right)
$$

Heat transfer between fluid 1 and glass:

$$
\begin{gathered}
h c, v_{f 1}=0.332 \frac{\lambda}{D} \operatorname{Re}^{0.5} \operatorname{Pr}^{0.33} \\
\text { where: } \operatorname{Re}=\frac{\rho V D}{\mu}, \operatorname{Pr}=\frac{\mu}{\rho \alpha} \text { for fluid } 1
\end{gathered}
$$

\section{Heat transfer between fluid 1 and absorber:}

The heat transfer coefficient between glass and fluid (f1) is assumed to be equal to heat transfer coefficient between the absorber and fluid (f1). Both plates are covered by the same fluid with the same fluid velocity and the glass and absorber have the same length.

The convective and radiative heat transfer coefficients of fluid $\mathrm{f} 1$ were used for return fluid $\mathrm{f} 2$.

\section{Thermo-Physical Properties}

The properties of the individual solar collector components are given in Table 1. The insulation used consists of crushed millet stem mixed with gum arabic binder. It is a very accessible material in rural areas and in large quantities, often unusable. 
Table 1. Thermo-physical properties of materials.

\begin{tabular}{ccccc}
\hline - & $\begin{array}{c}\text { Specific heat } \\
(\mathrm{kJ} / \mathrm{kg} \cdot \mathrm{K})\end{array}$ & $\begin{array}{c}\text { Thermal } \\
\text { conductivity }\left(\mathrm{W} \cdot \mathrm{m}^{-1} \cdot \mathrm{K}^{-1}\right)\end{array}$ & $\begin{array}{c}\text { Density } \\
\left(\mathrm{kg} \cdot \mathrm{m}^{-3}\right)\end{array}$ & $\begin{array}{c}\text { Absorption } \\
\text { coefficient }\end{array}$ \\
\hline Glass & 840 & 0.0263 & 1375 & 0.05 \\
Absorber & 398 & 384 & 8900 & 0.95 \\
Insulating & 794.76 & 0.12 & 435 & - \\
\hline
\end{tabular}

\section{Two-Dimensional Solar Collector Modeling}

The system is modeled by Comsol multiphysics 3.5 code taking into account the couplings of conductive, convective and radiative heat transfers between the fluid flow and the solid components of the solar collector. Figure 4 shows the temperature evolution and flow direction of the heat transfer medium.

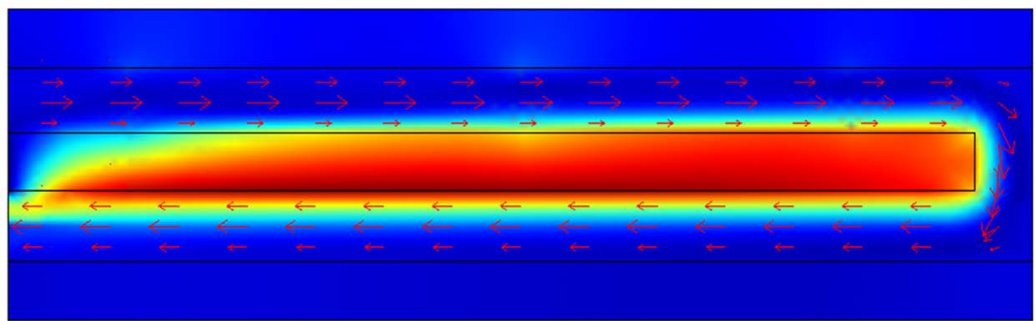

Figure 4. Temperature field over the solar collector.

The influence of the grid number on the temperature is presented in Table 2. In the following conditions: Solar heat flux $G_{\max }=800 \mathrm{~W} / \mathrm{m}^{2}, \alpha=0.9$, air $\rho=1.2$ $\mathrm{kg} / \mathrm{m}^{3}, C_{p}=1.006 \mathrm{~J} /(\mathrm{kg} \cdot \mathrm{K})$ and $\mu=10^{-5} \mathrm{~Pa} \cdot \mathrm{s}$ and physical properties presented in Table 1.

Table 2. Influence of mesh size.

\begin{tabular}{rcc}
\hline $\mathrm{N}$ & Tmax & Tmin \\
\hline 295 & 568,342 & 271,659 \\
1180 & 577,419 & 271,769 \\
4720 & 579,712 & 271,769 \\
18880 & 579,807 & 273,15 \\
75520 & 579,74 & 273,15 \\
\hline
\end{tabular}


Thus for Comsol the elements were defined with a number of degrees of freedom of 123,928 , a number of mesh points equal to 9613 , a number of meshelements corresponding to 18880 essentially composed of triangular meshes, with 848 delimiting elements for 12 vertices. The minimum quality of the elements is 0.652 for an element area ratio of 0.275 .

The variation in mesh size has a slight influence on temperatures for numbers of elements ranging from 295 to 4720, although not optimal. It becomes regular from a number of elements equal to 18,880 , which was chosen for its comparison with the thermal performance of the solar collector under working conditions (Table 1).

\section{Numerical Results}

The system of Equations (2) to (6) is discretized by finite differences method and then solved using Gauss-Seidel's iterative method.

\section{Air temperature evolution in the solar collector}

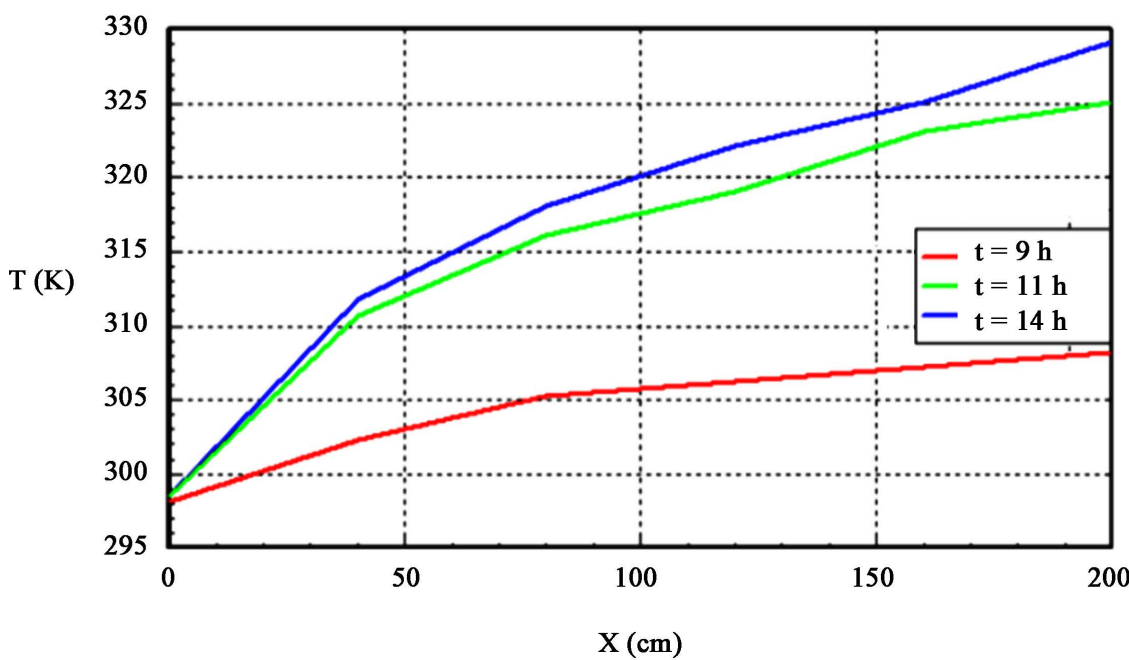

Figure 5. Evolution of the upper air temperature Tf1 along the solar collector

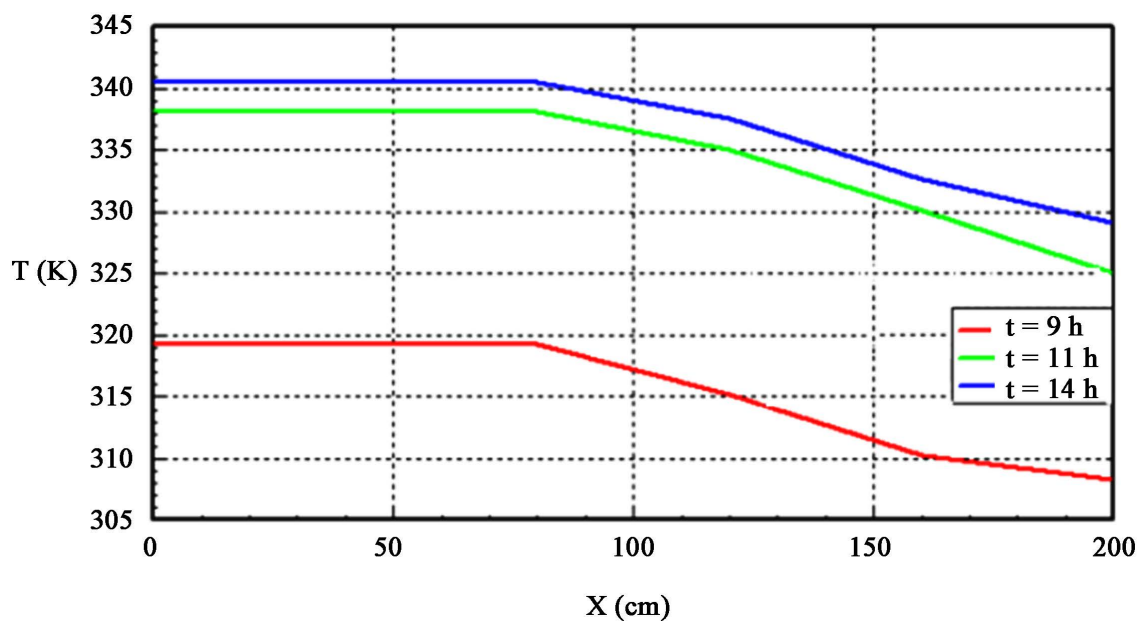

Figure 6. Temperature evolution of the lower air temperature Tf2 along the sensor. 
For a fixed flow rate of $0.023 \mathrm{~kg} / \mathrm{s}$, inlet air temperature of $298 \mathrm{~K}$ and solar heat flux ranging from 600 to $900 \mathrm{~W} / \mathrm{m}^{2}$, Figure 5 and Figure 6 shows respectively the air temperature evolution along the upper channel $\mathrm{T}_{\mathrm{f} 1}$ and lower channel $\mathrm{T}_{\mathrm{f} 2}$ at $9 \mathrm{~h}, 11 \mathrm{~h}$ and $14 \mathrm{~h}$. The maximum of air temperature flowing through the solar air collector, went respectively to $308 \mathrm{~K}, 325 \mathrm{~K}$ and $329 \mathrm{~K}$ (59 $\mathrm{C}$ maximum temperature). There is a temperature difference of $31 \mathrm{C}$ between the inlet temperature and the outlet temperature at $2 \mathrm{pm}$ due to the temperature gradient of interest in the flow.

The air enters the second channel with the outlet temperature of $T_{f 1}$. Thus the lower air temperature through the solar collector at the return flow went respectively up to $320 \mathrm{~K}(47 \mathrm{C}), 338 \mathrm{~K}(65 \mathrm{C})$ and $341 \mathrm{~K}(68 \mathrm{C})$ output temperature. A temperature difference of $17 \mathrm{C}$ is less important than in the first channel and remains relatively constant when the thermal equilibrium is reached (from 70 cm onwards).

\section{Influence of mass flow rate}

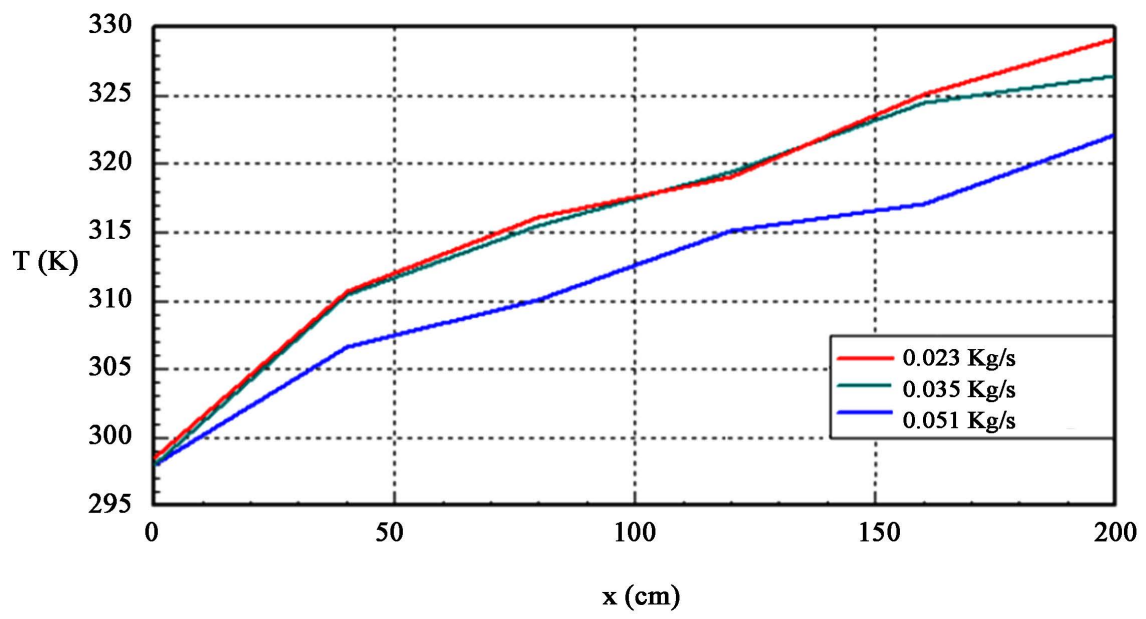

Figure 7. Distribution of the upper air temperature $\mathrm{T}_{\mathrm{fl}}$ for different mass flow rates at $14 \mathrm{~h}$.

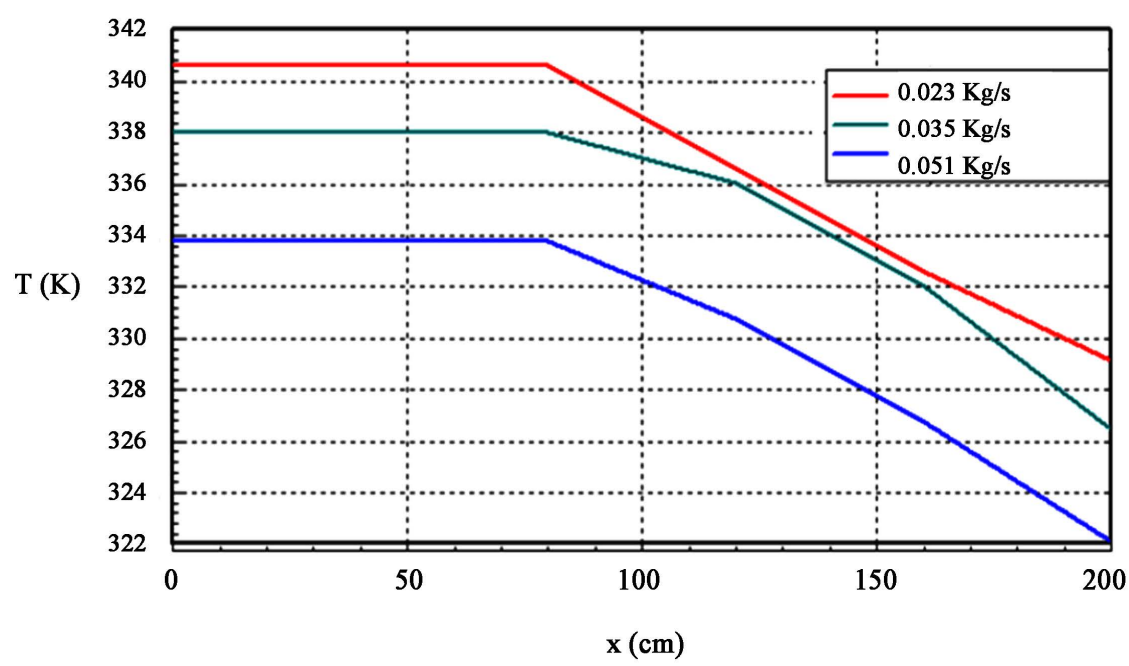

Figure 8. Distribution of the lower air temperature $\mathrm{T}_{\mathrm{f} 2}$ for different mass flow rates at $14 \mathrm{~h}$. 
For a solar heat flux of $900 \mathrm{~W} / \mathrm{m}^{2}$ at $14 \mathrm{~h}$, Figure 7 and Figure 8 show the effect of mass flow on the air outlet temperature in the solar collector. It can be seen that for $0.023 \mathrm{~kg} / \mathrm{s}, 0.035 \mathrm{~kg} / \mathrm{s}$ and $0.051 \mathrm{~kg} / \mathrm{s}$, the output temperatures of the heat transfer medium are $341 \mathrm{~K}(68 \mathrm{C}), 338 \mathrm{~K}(65 \mathrm{C})$ and $334 \mathrm{~K}(61 \mathrm{C})$ respectively. Thus, it can be seen that the more the flow rate tends towards its minimum value, the higher is the air outlet temperature. This is due to the length of time, more or less long, that the fluid stays in the solar collector, which causes more exchange between walls and air.

\section{Comparison of numerical results}

Figure 9 and Figure 10 show a comparison of temperature changes obtained with the two approaches (global model and Comsol).

For a flow rate of $0.023 \mathrm{~kg} / \mathrm{s}$ and solar heat flux of $900 \mathrm{~W} / \mathrm{m}^{2}$, the analysis of the obtained results shows a small difference of $7 \mathrm{C}$ between the two models (Figure 9 and Figure 10). This difference can be explained by the very nature of the two models studied, the first one (global model) being more global based mainly on a good knowledge of the heat transfer coefficients, the second

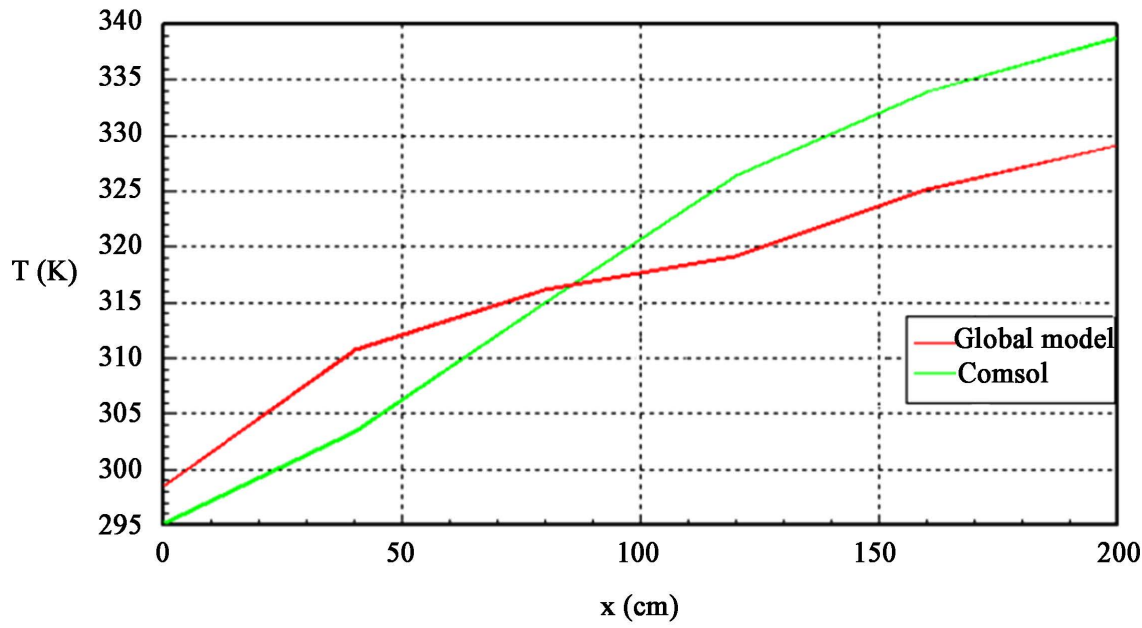

Figure 9. Distribution of temperatures $\mathrm{T}_{\mathrm{f} 1}$ of the upper canal.

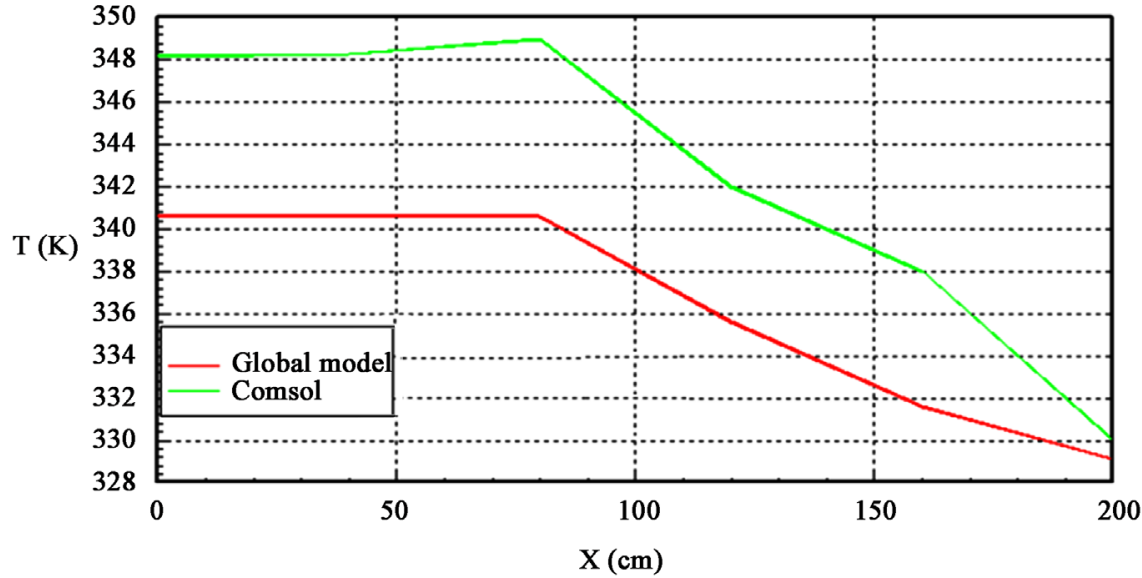

Figure 10. Distribution of temperatures $\mathrm{T}_{\mathrm{f} 2}$ of the lower canal. 
(Comsol) is more complete because it is based on the conservation equations of mass, momentum and energy, and associated boundary conditions. This enabled us to validate the global model.

\section{Comparison with Experimental Results}

Figure 11 and Figure 12 show the evolution of the air temperature throughout the solar collector with a flow rate of $0.023 \mathrm{~kg} / \mathrm{s}$ using theoretical and experimental models. For the same rate fixed at $0.023 \mathrm{~kg} / \mathrm{s}$ in the experiment as in the numerical resolution with irradiation of $600 \mathrm{~W} / \mathrm{m}^{2}$ and $900 \mathrm{~W} / \mathrm{m}^{2}$ at $9 \mathrm{~h}$ and 14 $\mathrm{h}$ respectively, we note that the pace of the experimental curves is relatively equal to that of the theoretical curves. At 9 o'clock, the experimental and numerical curves have the same output temperature $320 \mathrm{~K}(47 \mathrm{C})$ and 14 o'clock respectively $335 \mathrm{~K}(62 \mathrm{C})$ and $341 \mathrm{~K}(63 \mathrm{C})$ with a deviation of $6 \mathrm{C}$. This difference can be explained by the thermal pressure losses of the solar collector in the experiment.

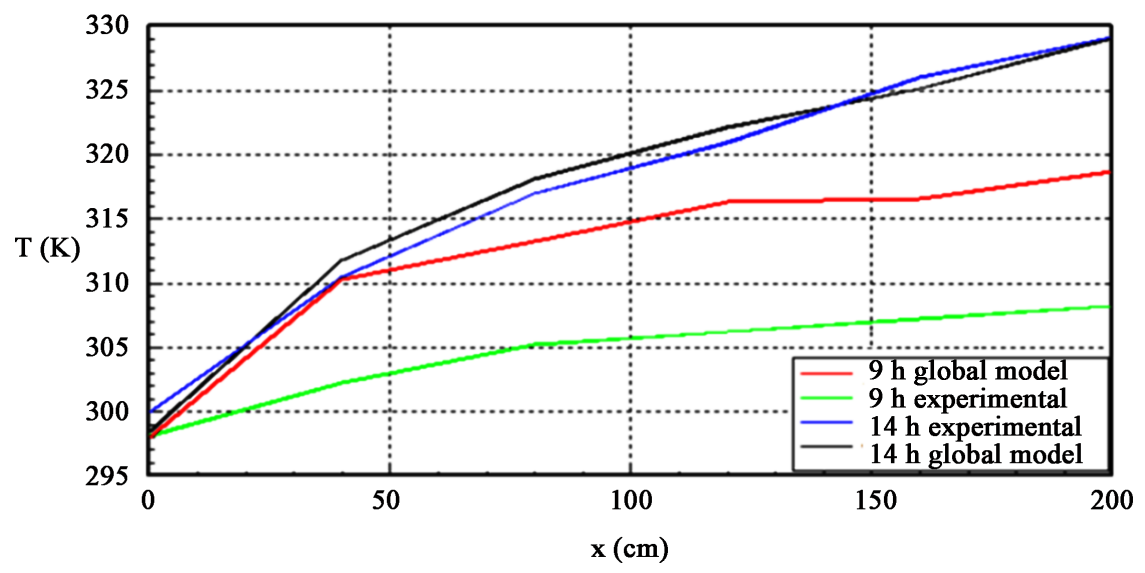

Figure 11. Numerical and experimental upper temperatures $T_{f 1}$.

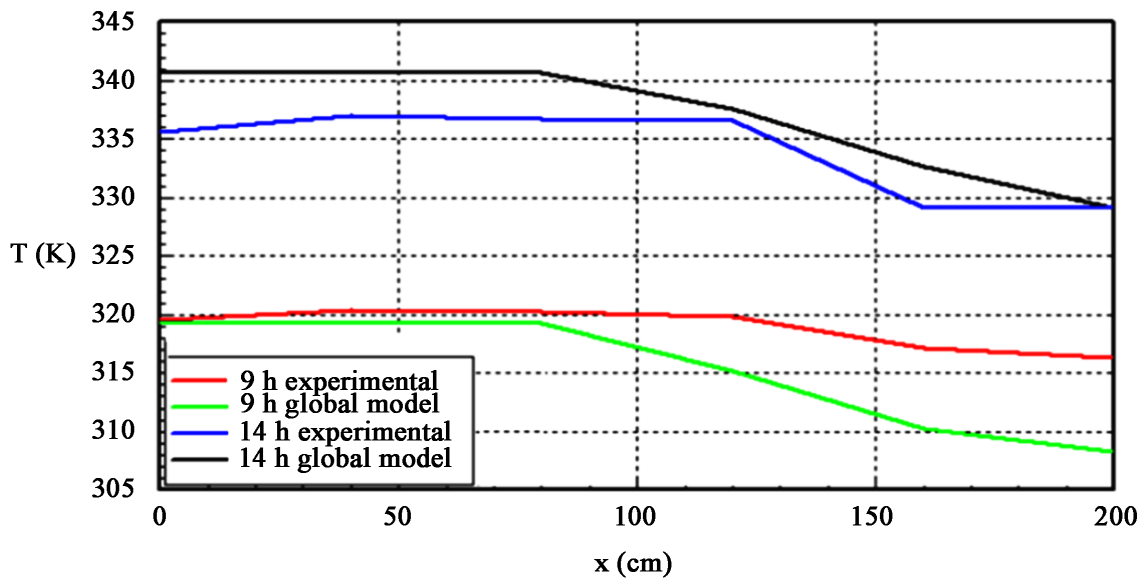

Figure 12. Numerical and experimental lower temperatures $T_{\mathrm{f} 2}$.

\section{Solarcollector Output}

The collector efficiency is defined as the ratio of the effective power $\phi_{u}$ extracted 
from the collector to the incident solar flux $G$. The effective power is evaluated using enthalpy balance.

$$
\begin{gathered}
\eta=\frac{\phi_{u}}{G S} \\
\text { with } \phi_{u}=C_{p} q_{m}\left(T_{o}-T_{i}\right)
\end{gathered}
$$

$T_{i}$ is the inlet temperature of the fluid f1 and $T_{o}$ is the outlet temperature of fluid f2.

Figure 13 shows the performance evolution of the solar collector for a fixed flow rate of $0.023 \mathrm{~kg} / \mathrm{s}$ and solar radiation of $900 \mathrm{~W} / \mathrm{m}^{2}$.

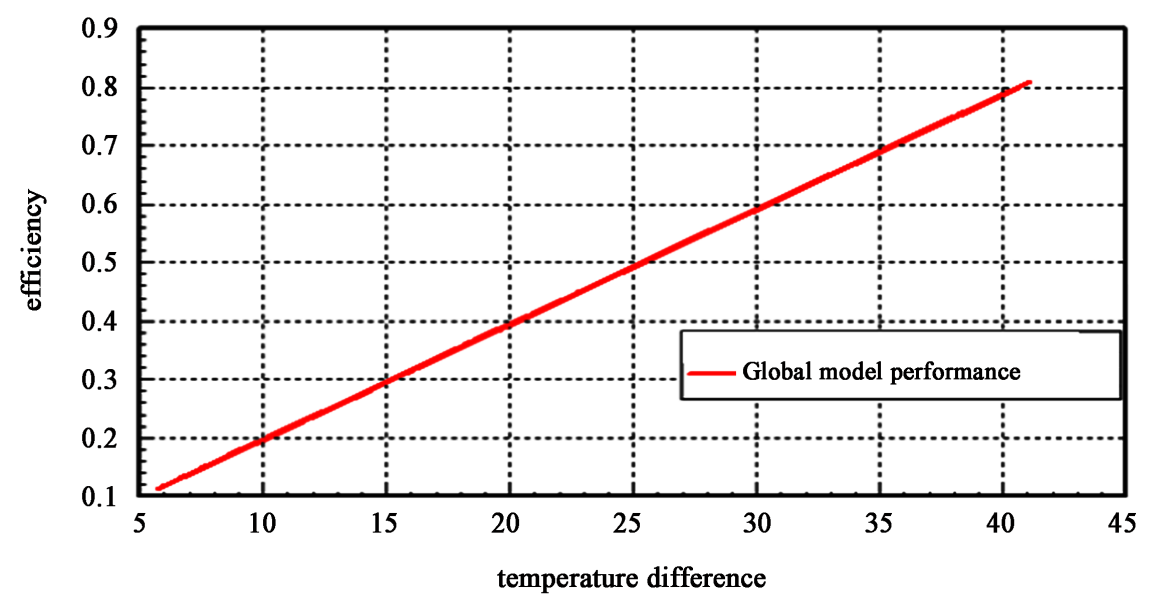

Figure 13. Performance of solar collector.

We note, that at this flow rate and maximum irradiation, that the optimal efficiency is $80 \%$ for a double-pass single-glazed air solar collector with crushed millet rod as insulator.

\section{Conclusions}

In this work, we have proposed a numerical and experimental study of a double air-pass solar collector with the objective of producing hot air to supply and improve drying techniques.

For this, we realized a double pass air solar collector and developed a global model and a numerical code to simulate and follow its thermal behavior. The solar collector is insulated thermally by a local material composed of easily accessible crushed millet stem.

The influences of masse flow rate on the air transient temperature response are presented along the solar collector at different instants and solar heat fluxes.

A good agreement between calculated and measured temperatures is observed in the pm of the day while in the am. The results show a significant difference due to the lateral thermal losses and also of the thermal inertia of the insulation material of the solar collector that are not taken into account in our global model. 
Further investigations are in progress with the COMSOL code, which offers the possibility of taking into account the three-dimensional effects and the nature of the materials used in the experimental setup.

\section{References}

[1] Benkhelifa, A. (1998) Optimisation d'un Capteur Solaire Plan. Rev. Energ. Ren. Physique Energétique, 13-18.

[2] Zaïd, A., Moulla, A., Hantala, M.S. and Desmons, J.Y. (2001) Amélioration des Performances des Capteurs Solaires Plans à Air: Application au Séchage de l'Oignon Jaune et du Hareng. Revue des Énergies Renouvelables, 4, 69-78.

[3] Lertsatitthanakorn, C., Khasee, N., Atthajariyakul, S., Soponronnarit, S., Therdyothin, A., Ryosuke, B. and Suzuki, O. (2008) Performance Analysis of a Double-Pass Thermoelectric Solar Air Collector. Solar Energy Materials \& Solar Cells, 92, 1105-1109. https://doi.org/10.1016/j.solmat.2008.03.018

[4] Yeh, H.M. and Lin, T.T. (1995) The Effect of Collectors Aspect Ratio on the Colectors Efficiency of Flat-Plate Solar Air. Energy, 20, 1041-1047. https://doi.org/10.1016/0360-5442(95)00053-J

[5] Njomo, D. (1998) Etude théorique du comportement thermique d'un capteur solaire plan à air à ouverture combinée plastique-vitre. Revue Générale de Thermique, 37, 973-980.

[6] Ali, S.Y. (2005) Study and Optimization of the Thermal Performances of the Offset Rectangular Plate Fin Absorber Plates, with Various Glazing. Renewable Energy, 30, 271-280. https://doi.org/10.1016/j.renene.2004.04.009

[7] Wijeysundera, N.E., An, L.L. and Tyioe, L.E. (1982) Thermal Performance Study of Two Pass Air Heaters. Solar Energy, 28, 363-370. https://doi.org/10.1016/0038-092X(82)90253-5

[8] Gunerhan, H. and Hepbasli, A. (2007) Determination of the Optimum Tilt Angle of Solar Collectors for Building Applications. Building and Environment, 42, 779-783. https://doi.org/10.1016/j.buildenv.2005.09.012

[9] Abene, A., Dubois, V., Le Ray, M. and Ouagued, A. (2004) Study of a Solar Air Flat Plate Collector: Use of Obstacles and Application for the Drying of Grape. Journal of Food Engineering, 65, 15-22. https://doi.org/10.1016/j.jfoodeng.2003.11.002

[10] Fudholi, A., Ruslan, M.H., Othman, M.Y., Yahya, M., Supranto, Zaharim, A. and Sopian, K. (2010) Collector Efficiency of the Double-Pass Solar Air Collectors with Fins. Proceedings of the 9th WSEAS International Conference on System Science and Simulation in Engineering (ICOSSSE'10), Iwate Prefectural University, Japan, 4-6 October, 428-434.

[11] Sopian, K., Supranto, Daud, W.R.W., Othman, M.Y. and Yatimc, V.B. (1999) Thermal Performance of the Double-Pass Solar Collector with and without Porous Media. Renewable Energy, 18, 557-564.

[12] Musa, E.A., Sopian, K. and Abdullah, S. (2004) Heat Transfer Analysis and Pressure Drop Correlations for the Double-Pass Solar Collector with Porous Media. Journal of Energy \& Environment, 3, 15-24.

[13] Mohamad, A.A. (1997) High Efficiency Solar Air Heater. Solar Energy, 60, 71-76. https://doi.org/10.1016/S0038-092X(96)00163-6

[14] Mokhtariet, F. and Semmar, D. (1999) Etude Expérimentale d'un Capteur Solaire à Air. Revue des Energies Renouvelables, 243-246. 
[15] Ho, C.D., Yeh, H.M., Cheng, T.W., Chen, T.C. and Wang, R.C. (2009) The Influences of Recycle on Performance of Baffled Double-Pass Flat-Plate Solar Air Heaters with Internal Fins Attached. Applied Energy, 86, 1470-1478.

https://doi.org/10.1016/j.apenergy.2008.12.013

[16] Omojaro, A.P. and Aldabbagh, L.B.Y. (2010) Experimental Performance of Single and Double Pass Solar Air Heater with Fins and Steel Wire Mesh as Absorber. Applied Energy, 87, 3759-3765.https://doi.org/10.1016/j.apenergy.2010.06.020.

[17] Moummi, N., Ali, S.Y., Moummi, A. and Desmons, J.Y. (2004) Energy Analysis of a Solar Air Collector with Rows of Fins. Renewable Energy, 29, 2053-2064. https://doi.org/10.1016/j.renene.2003.11.006

[18] Koyuncu, T. (2006) Performance of Various Designs of Solar Air Heaters for Crop Drying Applications. Renewable Energy, 31, 1073-1088.

https://doi.org/10.1016/j.renene.2005.05.017

[19] Zerrouki, A., Tedjiza, B. and Said, N. (2002) Modélisation des Pertes Thermiques dans un Capteur Solaire à Air à deux Passes. Revue des Energies Renouvelables, 5, 49-58.

[20] Naphon, P. (2005) Effect of Porous Media on the Performance of the Double-Pass Flat Plate Solar Air Heater. International Communications in Heat and Mass Transfer, 32, 140-150. https://doi.org/10.1016/j.icheatmasstransfer.2004.11.001

[21] Kumar, R. and Rosen, M.A. (2011) Performance Evaluation of a Double Pass PV/T Solar Air Heater with and without Fins. Applied Thermal Engineering, 31, 1402-1410.

[22] Ramani, B.M., Gupta, A. and Kumar, R. (2010) Performance of a Double Pass Solar Air Collector. Solar Energy, 84, 1929-1937.

[23] Jain, D. and Jain, R.K. (2004) Performance Evaluation of an Inclined Multi-Pass Solar Air Heater with In-Built Thermal Storage on Deep-Bed Drying Application. Journal of Food Engineering, 65, 497-509. https://doi.org/10.1016/j.jfoodeng.2004.02.013 


\section{Nomenclature}

$C_{p}$ : specific heat $(\mathrm{kJ} / \mathrm{kg} \cdot \mathrm{K})$.

$D$ : hydraulic diameter

$S$ s surface

$e$ : thickness of the fluid channel (m)

$F$ : shape factor

$G$ : solar heat flux

$h_{\dot{c}}$ convective heat transfer coefficient $\left(\mathrm{W} / \mathrm{m}^{2} \cdot \mathrm{K}\right)$

$h_{r}$ : radiative heat transfer coefficient $\left(\mathrm{W} / \mathrm{m}^{2} \cdot \mathrm{K}\right)$

$N u$ : Nusselt number

Pr: Prandtl number

$q_{m}$ : mass flow rate of the fluid $(\mathrm{kg} / \mathrm{s})$

Re: Reynolds number.

$T$ : temperature $(\mathrm{K})$.

$V$ : fluid velocity $(\mathrm{m} / \mathrm{s})$.

\section{Greek Symbols}

$\alpha$ : absorption coefficient/diffusivity

$\tau$. transmission coefficient

$\rho$ : density $\left(\mathrm{kg} / \mathrm{m}^{3}\right)$.

$\sigma$. Stephan Boltzmann constant $\left(\sigma=5.673 \times 10^{-8} \mathrm{~W} \cdot \mathrm{m}^{-2} \cdot \mathrm{K}^{-4}\right)$

E. emissivity coefficient

$\lambda$ : thermal conductivity

$\eta$ : thermal efficiency.

$\phi_{u}:$ effective power

\section{Subscripts}

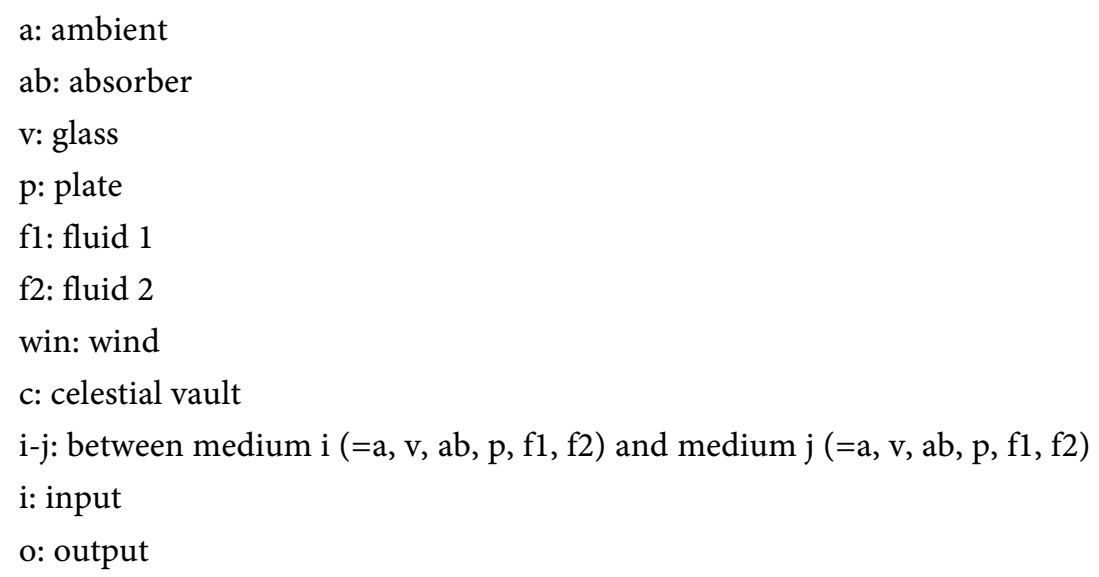

